\title{
Alternaria malicola sp. nov., a New Pathogen Causing Fruit Spot on Apple in China
}

J. L. Dang, State Key Laboratory of Crop Stress Biology in Arid Areas and College of Plant Protection, Northwest A\&F University, Yangling, Shaanxi, 712100, China; M. L. Gleason, Department of Plant Pathology and Microbiology, Iowa State University, Ames 50011; and L. N. Li, C. Wang, C. K. Niu, R. Zhang, and G. Y. Sun, ${ }^{\dagger}$ State Key Laboratory of Crop Stress Biology in Arid Areas and College of Plant Protection, Northwest A\&F University

\begin{abstract}
Alternaria spp. are pathogens of several diseases that pose significant threats to apple production. Several putative Alternaria sp. isolates were obtained from lesions of a disease commonly referred to as black dot on apple fruit in Shaanxi Province, China. Pathogenicity tests using mycelial plugs and conidial suspensions indicated that this isolate could cause leaf blotch, as well as moldy core and black dot on fruit. On the basis of sequence analysis of glyceraldehyde-3-phosphate dehydrogenase (GAPDH), RNA polymerase second largest subunit, and translation

elongation factor 1- $\alpha$, an isolate clustered with the Alternaria sect. Ulocladioides. By combining GAPDH, major allergen Alta1, mating type protein 1-2-1, and the AGA1 gene sequence analysis and morphological description, the isolates were identified as a new species named Alternaria malicola. Our finding expands the documented diversity of apple pathogens within the genus Alternaria and clarifies the taxonomy of the pathogen assemblage that may be associated with three apple diseases.
\end{abstract}

The genus Alternaria consists of a diverse group of pathogens, saprotrophs, and endophytes. They have a global distribution and can be found on and in a large variety of crop plants, ornamentals, fruit trees, and other hosts. Saprophytic species cause putrefaction and sometimes produce mycotoxins in foods and other biomaterials (Bottalico and Logrieco 1992; Ren et al. 1998). Plant-pathogenic Alternaria spp. can reduce crop yield and pose serious threats to agricultural production (Strandberg 1992), causing a wide range of symptoms, including leaf spot, blossom rot, and fruit rot and blight (Andersen et al. 2005).

Several Alternaria spp. cause Alternaria leaf blotch, moldy core, and black dot diseases on apple, threatening apple production in many areas of the world (Filajdic and Sutton 1991). In China, Alternaria leaf blotch of apple was first reported in the 1970s, and the disease is currently considered to be among the four most serious diseases in all major production areas of that country (Hu et al. 2006; Li et al. 2011). The causal agent of Alternaria leaf blotch of apple was originally identified as Alternaria mali Roberts in the United States (Roberts 1924). Sawamura (1962) indicated that the leaf blotch pathogen was Alternaria alternata $\mathrm{f}$. sp. mali on the basis of the role of its host-specific AM toxin. Moldy core is an economically important apple disease worldwide that reduces apple fruit quality and quantity. The genus Alternaria was considered to be associated with moldy core of apple (Combrink et al. 1985; Serdani et al. 1998; Spotts 1990). A. alternata, A. arborescens, A. tenuissima, and $A$. infectoria were later identified, and A. tenuissima was pinpointed as the main pathogen that caused moldy core in China (Gao et al. 2013).

Black dot (also known as black spot) on apple was first noted in China during the 1990s, after widespread introduction of the practice of bagging apple fruit during the period of fruit development. The disease is harmful to the quality of the fruit. Black to brown spots ( 1 to $5 \mathrm{~mm}$ in diameter) appear in the calyx dimple of the fruit; the lesion is sunken, and tissue in the center of the lesion dries and

${ }^{\dagger}$ Corresponding author: G. Y. Sun; E-mail: sgy@nwsuaf.edu.cn

Funding: This work was supported by the National Natural Science Foundation of China (31772113) and the China Agriculture Research System (CARS-27)

Accepted for publication 24 December 2017.

(c) 2018 The American Phytopathological Society may crack (Wang et al. 2014). The fungi Cylindrosporium pomi C. Brooks, Phoma pomi Pass. (Xu et al. 2000), Trichothecium roseum (Pers.) Link, Alternaria spp. (Hao et al. 2004), and Acremonium strictum $\mathrm{W}$. Gams were considered to be causal agents of black dot in China (Guo et al. 2005).

The objective of this study was to identify the species of Alternaria isolates obtained from black dot symptoms on bagged apple fruit, based on morphological characteristics and a phylogenetic analysis of the glyceraldehyde-3-phosphate dehydrogenase (GAPDH), RNA polymerase second largest subunit (RPB2), translation elongation factor 1- $\alpha$ (TEF1), major allergen Alta1 (Alta1), mating type protein (MAT1-2-1), and the AGA1 (AGA) gene.

\section{Materials and Methods}

Isolates. Twelve apple fruit (Malus domestica 'Fuji') exhibiting symptoms of disease were collected in 2015 from commercial orchards located in Baishui and Qianxian Counties of Shaanxi Province. Two putative Alternaria isolates (QXHD_10 and BSBD_86) used in this study were obtained from the margins of black dot lesions on the pericarp and cultured on potato dextrose agar (PDA) slants at $25^{\circ} \mathrm{C}$ in darkness for a week. Purified colonies were preserved in glycerol $(15 \%)$ at $-80^{\circ} \mathrm{C}$ in the Fungal Herbarium of Northwest A\&F University, Yangling, Shaanxi Province, China. For comparative purposes, 10 species (Alternaria alternariae, A. obovoidea, Ulocladium allii-tuberosi, U. chartarum, U. consortiale, U. dauci, $U$. multiforme, $U$. oudemansii, U. terricola, and $U$. zantedeschiae) (Table 1) were obtained from the Herbarium of Shandong Agricultural University, Department of Plant Pathology.

A representative isolate, QXHD_10, was deposited in the China General Microbiological Culture Collection Center (CGMCC) (Beijing) and dried cultures were deposited at the Herbarium Mycologicum Academiae Sinicae (HMAS) (Beijing). New species names and descriptions were deposited in MycoBank (www.MycoBank.org) (Crous et al. 2004). The isolate of Alternaria and GenBank numbers used in the study are shown in Table 2.

Pathogenicity tests on apple. Mycelial plug method. Isolate QXHD_10 was used for pathogenicity tests on pericarps of cultivars Golden Delicious, Red Delicious, Gala, and Fuji. Five fruit of each cultivar were used for each inoculation method. Mature asymptomatic fruit harvested from a commercial orchard located near Yangling were cleaned with pure water and wiped gently with cotton wool dipped in $75 \%$ ethanol for 30 to $40 \mathrm{~s}$, then air dried before inoculation. After the culture was incubated for a week in darkness at $25^{\circ} \mathrm{C}, 0.5$-cm-diameter plugs containing both hyphae and conidia were excised from the actively growing margin of 
the colony and placed on the calyx dimple of the fruit (two plugs per fruit), with the culture side facing the fruit. Sterile water and agar plugs without the fungus were used as controls. Inoculated and control fruit were sealed in individual plastic bags with wet cotton wool (soaked with sterile water) to provide continuous high relative humidity (>90\%) and incubated at $25^{\circ} \mathrm{C}$ in darkness.

Conidial suspension method. To produce abundant conidia, single-conidium isolates were grown on potato-carrot agar (PCA; $20 \mathrm{~g}$ of potato, $20 \mathrm{~g}$ of carrot, $20 \mathrm{~g}$ of agar, and 1 liter of distilled water) for 2 weeks under cool-white fluorescent light with a regime of alternating $8 \mathrm{~h}$ of light and $16 \mathrm{~h}$ of darkness at 20 to $23^{\circ} \mathrm{C}$ (Simmons 1998). Suspensions were then prepared by flooding culture dishes with sterile distilled water and disrupting the spores using a sterile scalpel (Harteveld et al. 2014), then filtering with Miracloth (polyester synthetic fiber filter cloth, aperture $=22$ to $25 \mu \mathrm{m}$; Calbiochem, Merck Co. Inc., Darmstadt, Germany) to remove hyphae and transferring conidial suspensions to three to four 1.5 -ml plastic centrifuge tubes. The suspensions were then refrigerated until use, which was within $2 \mathrm{~h}$ of preparation. Conidial suspensions ( $1 \mathrm{ml}$ per fruit) were brushed on pericarps of apple fruit with a sterile calligraphy brush. All fruit were cleaned with pure water and wiped gently with cotton wool dipped in $75 \%$ ethanol for 30 to $40 \mathrm{~s}$ to remove possible adhering microbes before inoculation.

Cultivars of apple used for conidial inoculation were Golden Delicious, Red Delicious, Gala, and Fuji. Inoculations were performed on wounded and nonwounded leaves, carpels, and pericarps. Sterilized insect mounting pins (size 2; length $=40 \mathrm{~mm}$ and width $=$ $0.38 \mathrm{~mm}$; Beijing Zhecheng Technology Co. Ltd., Beijing) were used to make 8 to 10 wounds (epidermal punctures) located arbitrarily on fruit; $100-\mu l$ conidial suspensions were applied to each wound. Five individual fruit were inoculated by each method. Symptom development was photographed 10 days after incubation at $25^{\circ} \mathrm{C}$ in darkness. Three replicates were prepared for per apple cultivar.

Leaves (fifth to sixth leaves, counting proximally from the shoot tip) and carpels attached to the excised fruit of Golden Delicious, Red Delicious, Gala, and Fuji apple were also inoculated. Conidial suspensions (100 $\mu$ l each) were placed on carpels or on each abaxial side of the excised leaves. Five samples of each tissue type per apple cultivar were inoculated by each method. The inoculated fruit were wrapped with plastic cling wrap, whereas inoculated leaves were placed in a sealed plastic bag with wet cotton wool to provide continuous high relative humidity $(>90 \%)$; both were incubated at $25^{\circ} \mathrm{C}$ in darkness. Symptom development was assessed 5 days after inoculation for carpels and 10 days after inoculation for leaves.

DNA extraction, polymerase chain reaction, and sequencing. The protocol of Pryor and Gilbertson (2000) was used to extract genomic DNA from mycelium of single-conidium-origin colonies grown on PDA plates at $25^{\circ} \mathrm{C}$ in darkness for 7 days. Six genes were amplified: GAPDH, RPB2, TEF1, Alta1, MAT1-2-1, and AGA. Primers used for amplification and sequencing were gpd 1 and gpd 2 for GAPDH (Berbee et al. 1999), fRPB2-5F2 (Sung et al. 2007) and fRPB2-7cR (Liu et al. 1999) for RPB2, EF1-728F and EF1-986R for TEF1 (Carbone and Kohn 1999), Alta1-F and Alta1-R for Alta1 (Hong et al. 2005), MAT1-2F and MAT1-2R for MAT1-2 (Geng et al. 2014), and AlphaboxF and AlphaboxR for AGA (Geng et al. 2014). The amplification reaction mixtures of GAPDH, RPB2, TEF1, and Altal gene, consisting of $1 \times$ polymerase chain reaction (PCR) buffer, $2 \mathrm{mM} \mathrm{MgCl}_{2}, 0.2 \mathrm{mM}$ each dNTP, $0.4 \mu \mathrm{M}$ each primer, $1 \mu \mathrm{l}$ of template DNA ( $2 \mu \mathrm{l}$ for RPB2 and TEF1), and $1 \mathrm{U}$ of Taq polymerase ( $2 \mathrm{U}$ for RPB2), were made up to a total volume of $25 \mu \mathrm{l}$ with sterile water. The PCR mixture for MAT1-2-1 and AGA gene amplifications contained $5 \mu \mathrm{l}$ of $10 \times$ ThermoPol reaction buffer $(200 \mathrm{mM}$ Tris- $\mathrm{HCl}$ [pH 8.3], $100 \mathrm{mM} \mathrm{KCl}, 100 \mathrm{mM}\left[\mathrm{NH}_{4}\right]_{2} \mathrm{SO}_{4}, 20 \mathrm{mM} \mathrm{MgSO}_{4}$, and $1 \%$ Triton X-100), $5 \mu$ l of $10 \mathrm{mM} \mathrm{MgSO}_{4}, 20 \mathrm{ng}$ of template genomic DNA, $0.4 \mu \mathrm{M}$ each primer, $4 \mu \mathrm{l}$ of $2.5 \mathrm{mM}$ dNTP, and $0.5 \mathrm{U}$ of AmpliTaq polymerase; total volume was adjusted to $50 \mu 1$ with deionized water (Geng et al. 2014). The PCR were performed on a Bio-Rad PCR System PTC-200TM. Conditions for PCR amplification consisted of an initial denaturation step of $5 \mathrm{~min}$ at $96^{\circ} \mathrm{C}$ followed by 30 cycles of $1 \mathrm{~min}$ at $96^{\circ} \mathrm{C}, 1 \mathrm{~min}$ at $56^{\circ} \mathrm{C}$, and $45 \mathrm{~s}$ at $72^{\circ} \mathrm{C}$ for GAPDH; $5 \mathrm{~min}$ at $94^{\circ} \mathrm{C}$ followed by 40 cycles of $30 \mathrm{~s}$ at $94^{\circ} \mathrm{C}, 30 \mathrm{~s}$ at $59^{\circ} \mathrm{C}$, and $45 \mathrm{~s}$ at $72^{\circ} \mathrm{C}$ for TEF1; 35 cycles of $1 \mathrm{~min}$ at $94^{\circ} \mathrm{C}, 30 \mathrm{~s}$ at $55^{\circ} \mathrm{C}$, and $30 \mathrm{~s}$ at $72^{\circ} \mathrm{C}$ for Altal and AGA; $1 \mathrm{~min}$ at $94^{\circ} \mathrm{C}, 30 \mathrm{~s}$ at $58^{\circ} \mathrm{C}$, and $1 \mathrm{~min}$ at $72^{\circ} \mathrm{C}$ for MAT1-2; followed by a final elongation

Table 1. Distinguishing characteristics of this new species and similar well known species of Ulocladium under growth conditions ${ }^{\mathrm{a}}$

\begin{tabular}{|c|c|c|c|c|c|c|}
\hline \multirow[b]{2}{*}{ Species } & \multicolumn{5}{|c|}{ Conidia } & \multirow[b]{2}{*}{$\begin{array}{l}\text { Conidiophores } \\
(\mu \mathbf{m})^{\mathbf{b}}\end{array}$} \\
\hline & Shape & Size $(\mu \mathrm{m})$ & $\begin{array}{l}\text { Transverse } \\
\text { septa }\end{array}$ & $\begin{array}{c}\text { Longitudinal or } \\
\text { oblique septa }\end{array}$ & Conidial wall & \\
\hline $\begin{array}{c}\text { Alternaria malicola } \\
\text { CGMCC3.18704 }\end{array}$ & $\begin{array}{l}\text { Spheroidal or } \\
\text { ellipsoid to long- } \\
\text { ellipsoid with a } \\
\text { slightly cuspidal } \\
\text { top }\end{array}$ & $16-35 \times 8-16$ & $1-5$ & $1-3$ & $\begin{array}{l}\text { Verrucose } \\
\text { protuberances or } \\
\text { densely tuberculate }\end{array}$ & $10-60 \times 3.0-4.5$ \\
\hline A. alternariae CBS 116328 & $\begin{array}{l}\text { Obovoid to broadly } \\
\text { obovoid }\end{array}$ & $18-35 \times 10-20$ & $1-5$ & $1-3$ & $\begin{array}{l}\text { Smooth or slightly } \\
\text { verrucose }\end{array}$ & $16-70 \times 2.5-4.0$ \\
\hline A. obovoidea CBS 101229 & $\begin{array}{l}\text { Broadly obovoid with } \\
\text { a conspicuously } \\
\text { pointed base }\end{array}$ & $20-28 \times 12.5-17$ & $3-4$ & $1-4$ & Punctulate to verrucose & $45-100 \times 3.5-6.0$ \\
\hline A. terricola CBS 202.67 & $\begin{array}{l}\text { Obovoid to broadly } \\
\text { ellipsoid }\end{array}$ & $13.5-22.5 \times 10-18.5$ & $1-2$ & $0-1$ & $\begin{array}{l}\text { Smooth or slightly } \\
\text { verruculose }\end{array}$ & $30-100 \times 4.0-5.0$ \\
\hline $\begin{array}{l}\text { Ulocladium allii-tuberosi } \\
\text { CBS } 124112\end{array}$ & Long-ellipsoid & $15-45.5 \times 8.5-15$ & $1-3$ & $0-3$ & Smooth & $85-130 \times 4.5-5.5$ \\
\hline U. chartarum CBS 200.67 & Ellipsoid or obovoid & $20-35.5 \times 10-20$ & $1-4$ & $0-2$ & Smooth or verrucose & $40-65 \times 3.0-5.0$ \\
\hline U. consortiale CBS 201.67 & $\begin{array}{l}\text { Obovoid or long- } \\
\text { ellipsoid }\end{array}$ & $20.5-41 \times 12-15$ & $1-5$ & $1-4$ & $\begin{array}{l}\text { Smooth or slightly } \\
\text { verruculose }\end{array}$ & $19-74 \times 3.0-4.5$ \\
\hline U. dauci CBS 102062 & Obovoid or spheroidal & $20.5-24.5 \times 11-14.5$ & $1-2$ & $1-2$ & $\begin{array}{l}\text { Densely tuberculate to } \\
\text { pustulate }\end{array}$ & $50-65 \times 4.0-5.0$ \\
\hline U. multiforme CBS102060 & Obovoid or spheroidal & $20-25 \times 15-18$ & $1-2$ & $1-2$ & $\begin{array}{l}\text { Densely tuberculate to } \\
\text { pustulate }\end{array}$ & $55-75 \times 4.5-5.0$ \\
\hline U. oudemansii CBS 137.81 & $\begin{array}{l}\text { Obovoid to broadly } \\
\text { ellipsoid }\end{array}$ & $25-30 \times 11-14$ & $3-5$ & $0-2$ & Smooth or verrucose & $110-200 \times 5.0-7.5$ \\
\hline $\begin{array}{l}\text { U. zantedeschiae CBS } \\
124113\end{array}$ & Ellipsoid or obovoid & $15.5-32.5 \times 7.5-14$ & $1-5$ & $1-5$ & Smooth or verrucose & $36-71 \times 3.0-5.0$ \\
\hline
\end{tabular}

${ }^{a}$ New species in this study are printed in bold.

${ }^{\mathrm{b}}$ Dimensions of conidiophores ( $\mu \mathrm{m}$, length $\times$ width at base). 
Table 2. Alternaria isolates used in the study with the corresponding GenBank accession numbers of gene sequences ${ }^{\mathrm{a}}$

\begin{tabular}{|c|c|c|c|c|c|c|c|}
\hline \multirow[b]{2}{*}{ Species name } & \multirow[b]{2}{*}{ Strain number } & \multicolumn{6}{|c|}{ GenBank accession numbers ${ }^{b}$} \\
\hline & & RPB2 & TEF1 & GAPDH & Alta1 & MAT1-2-1 & AGA \\
\hline Alternaria alternantherae & CBS 124392 & KC584374 & KC584633 & KC584096 & $\ldots$ & $\ldots$ & $\ldots$ \\
\hline A. alternata & CBS 916.96 & KC584375 & KC584634 & AY278808 & AY563301 & AB009452 & AB239917 \\
\hline A. argyranthemi & CBS 116530 & KC584378 & KC584637 & KC584098 & $\ldots$ & $\ldots$ & $\ldots$ \\
\hline A. armoraciae & CBS 118702 & KC584379 & KC584638 & KC584099 & $\ldots$ & $\ldots$ & $\ldots$ \\
\hline A. brassicicola & CBS 118699 & KC584383 & KC584642 & KC584103 & $\ldots$ & $\ldots$ & $\ldots$ \\
\hline A. capsici-annui & CBS 504.74 & KC584385 & KC584644 & KC584105 & $\ldots$ & $\ldots$ & $\ldots$ \\
\hline A. cheiranthi & CBS 109384 & KC584387 & KC584646 & KC584107 & $\ldots$ & $\ldots$ & $\ldots$ \\
\hline A. cinerariae & CBS 116495 & KC584389 & KC584648 & KC584109 & $\ldots$ & $\ldots$ & $\ldots$ \\
\hline A. dianthicola & CBS 116491 & KC584394 & KC584653 & KC584113 & $\ldots$ & $\ldots$ & $\ldots$ \\
\hline A. ellipsoidea & CBS 119674 & KC584396 & KC584655 & KC584115 & $\ldots$ & $\ldots$ & $\ldots$ \\
\hline A. eryngii & CBS 121339 & KC584397 & KC584656 & AY562416 & $\ldots$ & $\ldots$ & $\ldots$ \\
\hline A. ethzedia & CBS 197.86 & KC584398 & KC584657 & AY278795 & $\ldots$ & $\ldots$ & $\ldots$ \\
\hline A. gaisen & CBS 632.93 & KC584399 & KC584658 & KC584116 & $\ldots$ & $\ldots$ & $\ldots$ \\
\hline A. gypsophilae & CBS 107.41 & KC584401 & KC584660 & KC584118 & $\ldots$ & $\ldots$ & $\ldots$ \\
\hline A. infectoria & CBS 210.86 & KC584404 & KC584662 & AY278793 & $\ldots$ & $\ldots$ & $\ldots$ \\
\hline A. japonica & CBS 118390 & KC584405 & KC584663 & KC584121 & $\ldots$ & $\ldots$ & $\ldots$ \\
\hline A. longipes & CBS 540.94 & KC584409 & KC584667 & AY278811 & $\ldots$ & $\ldots$ & $\ldots$ \\
\hline A. mimicula & CBS 118696 & KC584411 & KC584669 & AY562415 & $\ldots$ & $\ldots$ & $\ldots$ \\
\hline A. molesta & CBS 548.81 & KC584412 & KC584670 & KC584125 & $\ldots$ & $\ldots$ & $\ldots$ \\
\hline A. panax & CBS 482.81 & KC584417 & KC584675 & KC584128 & $\ldots$ & $\ldots$ & $\ldots$ \\
\hline A. porri & CBS 116698 & KC584421 & KC584679 & KC584132 & $\ldots$ & $\ldots$ & $\ldots$ \\
\hline A. radicina & CBS 245.67 & KC584423 & KC584681 & KC584133 & $\ldots$ & $\ldots$ & $\ldots$ \\
\hline A. selini & CBS 109382 & KC584426 & KC584684 & AY278800 & $\ldots$ & $\ldots$ & $\ldots$ \\
\hline A. solani & CBS 116651 & KC584430 & KC584688 & KC584139 & $\ldots$ & $\ldots$ & $\ldots$ \\
\hline A. sonchi & CBS 119675 & KC584433 & KC584691 & KC584142 & $\ldots$ & $\ldots$ & $\ldots$ \\
\hline A. tenuissima & CBS 918.96 & KC584435 & KC584693 & AY278809 & $\ldots$ & $\ldots$ & $\ldots$ \\
\hline A. thalictrigena & CBS 121712 & KC584436 & KC584694 & KC584144 & $\ldots$ & $\ldots$ & $\ldots$ \\
\hline A. triglochinicola & CBS 119676 & KC584437 & KC584695 & KC584145 & $\ldots$ & $\ldots$ & $\ldots$ \\
\hline A. vaccariicola & CBS 118714 & KC584439 & KC584697 & KC584147 & $\ldots$ & $\ldots$ & $\ldots$ \\
\hline A. penicillata & CBS 116608 & KC584440 & KC584698 & FJ357299 & $\ldots$ & $\ldots$ & $\ldots$ \\
\hline A. cetera & CBS 121340 & KC584441 & KC584699 & AY562398 & $\ldots$ & $\ldots$ & $\ldots$ \\
\hline A. embellisia & CBS 339.71 & KC584449 & KC584708 & KC584155 & $\ldots$ & $\ldots$ & $\ldots$ \\
\hline A. conoidea & CBS 132.89 & KC584452 & KC584711 & FJ348227 & $\ldots$ & $\ldots$ & $\ldots$ \\
\hline A. eureka & CBS 193.86 & KC584456 & KC584715 & JN383471 & $\ldots$ & $\ldots$ & $\ldots$ \\
\hline A. lolii & CBS 115266 & KC584460 & KC584719 & JN383473 & $\ldots$ & $\ldots$ & $\ldots$ \\
\hline A. botryospora & CBS 478.90 & KC584461 & KC584720 & AY278831 & $\ldots$ & $\ldots$ & $\ldots$ \\
\hline A. phragmospora & CBS 274.70 & KC584462 & KC584721 & JN383474 & $\ldots$ & $\ldots$ & $\ldots$ \\
\hline A. scirpicola & CBS 481.90 & KC584469 & KC584728 & KC584163 & $\ldots$ & $\ldots$ & $\ldots$ \\
\hline A. alternariae & CBS 126989 & KC584470 & KC584730 & AY278815 & $\ldots$ & $\ldots$ & $\ldots$ \\
\hline Stemphylium herbarum & CBS 191.86 & KC584471 & KC584731 & AF443884 & $\ldots$ & $\ldots$ & $\ldots$ \\
\hline A. leucanthemi & CBS 422.65 & KC584473 & KC584733 & KC584165 & $\ldots$ & $\ldots$ & $\ldots$ \\
\hline A. alternariae & CBS 116328 & & & AY278815 & AY563316 & HQ906726 & HQ906746 \\
\hline A. aspera & CBS 115269 & KC584474 & KC584734 & KC584166 & & & \\
\hline A. atra & CBS 195.67 & KC584475 & KC584735 & KC584167 & AY563318 & HQ906727 & HQ906747 \\
\hline Ulocladium allii-tuberosi & CBS 124112 & $\ldots$ & $\ldots$ & KF533907 & KF533896 & KF533884 & HQ906745 \\
\hline$U$. arborescens & CBS 115269 & $\ldots$ & $\ldots$ & KF533910 & KF533899 & KF533887 & $\ldots$ \\
\hline A. bornmuelleri & DAOM 231361 & KC584491 & KC584751 & FJ357305 & $\ldots$ & $\ldots$ & $\ldots$ \\
\hline A. botrytis & CBS 197.67 & KC584476 & KC584736 & KC584168 & $\ldots$ & $\ldots$ & $\ldots$ \\
\hline Alternaria sp. & CBS 198.67 & KC584477 & KC584737 & KC584169 & AY563317 & KF533888 & HQ906748 \\
\hline A. brassicae-pekinensis & CBS 121493 & KC584478 & KC584738 & KC584170 & KF533892 & HQ906728 & HQ906749 \\
\hline A. cantlous & CBS 123007 & KC584479 & KC584739 & KC584171 & EU684146 & KF533881 & HQ906750 \\
\hline U. capsicuma & CBS 120006 & KC584480 & KC584740 & AY762950 & EU684149 & HQ906740 & HQ906751 \\
\hline U. castaneae & CBS 124390 & $\ldots$ & $\ldots$ & KF533902 & KF533891 & HQ906729 & HQ906752 \\
\hline U. chartarum & CBS 200.67 & $\ldots$ & $\ldots$ & AY278819 & AY563319 & HQ906741 & HQ906753 \\
\hline$U$. consortiale & CBS 201.67 & $\ldots$ & $\ldots$ & FJ266494 & FJ266509 & HQ906730 & HQ906754 \\
\hline A. consortialis & CBS 104.31 & KC584482 & KC584742 & KC584173 & $\ldots$ & $\ldots$ & $\ldots$ \\
\hline A. cucurbitae & CBS 483.81 & KC584483 & KC584743 & AY562418 & AY563315 & HQ906731 & HQ906755 \\
\hline U. dauci & CBS 102062 & $\ldots$ & $\ldots$ & FJ266495 & FJ266510 & HQ906732 & HQ906756 \\
\hline U. microsporum & CBS 124391 & $\ldots$ & $\ldots$ & KF533901 & KF533890 & KF533880 & HQ906758 \\
\hline A. multiformi & CBS 102060 & KC584484 & KC584744 & KC584174 & $\ldots$ & $\ldots$ & $\ldots$ \\
\hline U. oblong-obovoideum & CBS 126317 & $\ldots$ & $\ldots$ & KF533904 & KF533893 & HQ906734 & HQ906759 \\
\hline A. obovoidea & CBS 101229 & KC584485 & KC584745 & FJ266498 & AY563315 & HQ906731 & HQ906755 \\
\hline U. oudemansii & CBS 137.81 & $\ldots$ & $\ldots$ & EU684152 & EU684148 & HQ906742 & HQ906761 \\
\hline U. septosporum & CBS 109.38 & $\ldots$ & $\ldots$ & FJ266500 & FJ266515 & HQ906743 & HQ906764 \\
\hline A. heterospora & CBS 123376 & KC584488 & KC584748 & KC584176 & EU855805 & KF533885 & HQ906765 \\
\hline U. sorghi & CBS 126315 & $\ldots$ & $\ldots$ & KF533909 & KF533898 & KF533886 & HQ906766 \\
\hline A. subcucurbitae & CBS 121491 & KC584489 & KC584749 & EU855803 & EU855807 & HQ906736 & HQ906767 \\
\hline A. terricola & CBS 202.67 & KC584490 & KC584750 & KC584177 & FJ266516 & HQ906744 & HQ906768 \\
\hline U. zantedeschiae & CBS 124113 & $\ldots$ & $\ldots$ & KF533900 & KF533889 & HQ906737 & HQ906769 \\
\hline A. malicola QXHD_10 & CGMCC3.18704 & MF426957 & MF426959 & MF426953 & MF426951 & MF426955 & MF426949 \\
\hline A. malicola BSBD_86 & $\ldots$ & MF426956 & MF426958 & MF426952 & MF426950 & MF426954 & MF426948 \\
\hline
\end{tabular}

a New species and sequences generated in this study are printed in bold.

b RPB2 = RNA polymerase II second largest subunit (RPB2) gene, TEF1 = translation elongation factor 1- $\alpha$ gene, GAPDH = glyceraldehyde-3-phosphate dehydrogenase gene, Alta1 = major allergen alta1 gene, MAT1-2-1 = mating type 1-2-1 gene, and AGA = G protein $\alpha$ subunit AGA1 gene 
step of 7 min at $72^{\circ} \mathrm{C}$. The partial RPB2 gene was obtained by using a touchdown PCR protocol of 5 cycles of $45 \mathrm{~s}$ at $94^{\circ} \mathrm{C}, 45 \mathrm{~s}$ at $60^{\circ} \mathrm{C}$, and $2 \mathrm{~min}$ at $72^{\circ} \mathrm{C}$; followed by 5 cycles with a $58^{\circ} \mathrm{C}$ annealing temperature and 30 cycles with a $54^{\circ} \mathrm{C}$ annealing temperature. Purifying and automated sequencing of the PCR products was performed at Organism Technology, Shanghai, China with forward and reverse primers.

Sequence alignment and phylogenetic analysis. All sequences generated in this study, as well as other sequences of Alternaria spp. and the outgroup sequences obtained from the National Center for Biotechnology Information's GenBank sequence database (Table 2), were imported into BioEdit v.7.0.5.2 (Hall 1999) for comparison and analysis. Stemphylium herbarum isolate CBS 191.86 and A. alternata isolate CBS 916.96 were used to root the three-locus GAPDH-RPB2-TEF1 and GAPDH-Alta1-MAT (1-2-1)-AGA phylogenetic trees. Preliminary alignments of the multiple sequences were conducted using MUSCLE (Edgar 2004), with manual adjustment using BioEdit for visual improvement where necessary.

We performed Bayesian and maximum-likelihood (ML) analyses of both the individual data partitions and the combined aligned dataset. Bayesian analyses were performed with MrBayes v. 3.2.1 (Ronquist and Huelsenbeck 2003). The Markov-Chain Monte Carlo analysis used four chains and started from a random tree topology. The sample frequency was set at 100 and the temperature value of the heated chain was 0.1 . The temperature value was lowered to 0.05 when the average standard deviation of split frequencies did not fall below 0.01 after 5 million generations (RPB2 and Pleosporineae phylogeny). Burn-in was set to $25 \%$ after which the likelihood values were stationary. ML analyses including 1,000 bootstrap replicates were run using RAxML v. 7.2.6 (Stamatakis 2006). The best nucleotide substitution model of different gene regions was selected by using MrModelTest v.2.3 (Nylander 2004).

Sequences of an isolate of $S$. herbarum (CBS 191.86) were used as the outgroup in the Alternaria phylogeny and sequences of $A$. alternata (CBS 916.96) were used in the Ulocladium phylogeny. The resulting trees were printed with TreeView v. 1.6.6 (Page 1996) and alignments and representative trees were deposited in TreeBASE (https://www.treebase.org).

Morphology of isolates. Hyphal tips of isolate QXHD_10 from mycelial growth that developed on PDA slants were transferred to PCA in plastic Petri dishes (Simmons and Roberts 1993) in vitro and descriptions of colony morphology were made after incubation for 7 days under cool-white fluorescent light with a regime of alternating $8 \mathrm{~h}$ of light and $16 \mathrm{~h}$ of darkness at 20 to $23^{\circ} \mathrm{C}$ (Simmons 1998). In order to measure and observe fungal structures, a sellotape technique was used for making slide preparations (Crous et al. 2009) with Shear's medium ( $3 \mathrm{~g}$ of potassium acetate, $60 \mathrm{ml}$ of glycerin, $90 \mathrm{ml}$ of $95 \%$ ethanol, and $150 \mathrm{ml}$ of water) as mounting fluid. At least 30 measurements $(\times 1,000$ magnification $)$ were made by Nikon NIS-Elements D 3.0 imaging software. The length/width ratio (L/W) of ascospores was measured according to the method of Verkley (1999) and the average was calculated.

To visualize how conidia, conidial hila, and conidiogenous scars were produced, scanning electron micrographs were taken
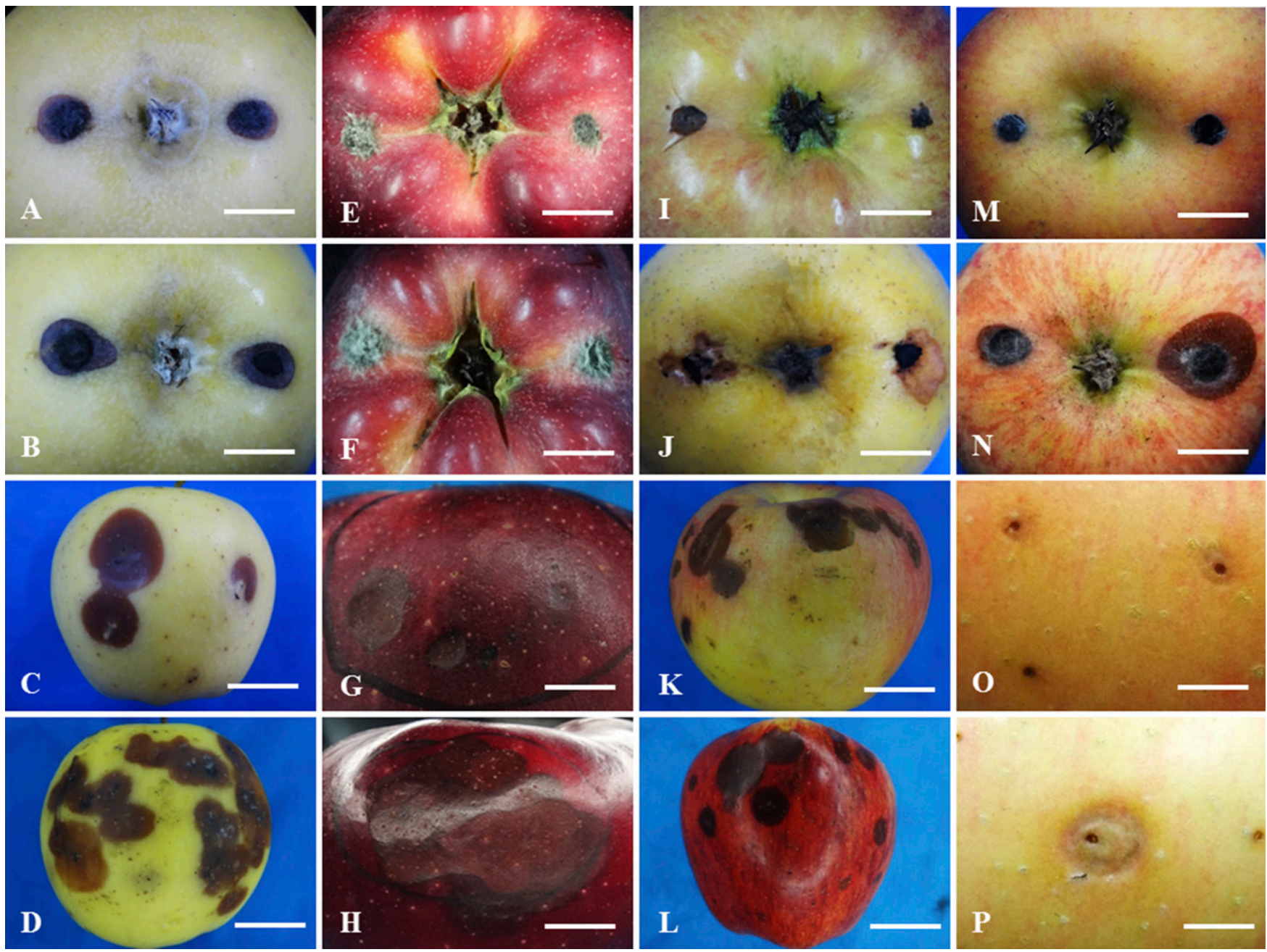

Fig. 1. Symptoms on pericarps of Golden Delicious, Red Delicious, and Gala inoculated with Alternaria malicola isolate QXHD_10. A to D, Golden Delicious; E to H, Red Delicious I to L, Gala; and M to P, Fuji. A, C, E, G, I, K, M, and O were inoculated without wounding; B, D, F, H, J, L, N, and P were wound inoculated. A, B, E, F, I, J, M, and N were inoculated by hyphae; $\mathrm{C}, \mathrm{D}, \mathrm{G}, \mathrm{H}, \mathrm{K}, \mathrm{L}, \mathrm{O}$, and $\mathrm{P}$ were inoculated by conidium suspensions. All symptoms were photographed 10 days after inoculation. $\mathrm{Scale}$ bars: $\mathrm{G}, \mathrm{H}, \mathrm{O}$, and $\mathrm{P}=1.0 \mathrm{~cm}$; others $=1.5 \mathrm{~cm}$. 
of isolate QXHD_10. After cultures were maintained on PCA for a week in darkness at $25^{\circ} \mathrm{C}, 5$-mm-diamater fragments of PCA with attached hyphae and conidia were fixed in $4 \%$ glutaraldehyde for $6 \mathrm{~h}$ and $1 \%$ osmium tetroxide in $0.1 \mathrm{M}$ cacodylate buffer ( $\mathrm{pH}$ 6.8) for $2 \mathrm{~h}$, followed by a series of ethanol rinses, after which the hyphae and conidia were dehydrated in a critical-point dryer, sputter coated with gold, and examined under a scanning electron microscope (Joel JSM 6360LV) at accelerating voltages of 15 and $25 \mathrm{kV}$.

\section{Results}

Pathogenicity tests. Ten days after inoculation with conidial suspensions, sunken and water-soaked spots appeared on both wounded and nonwound pericarps (Fig. 1). The lesions were larger $($ diameter $=$ 0.5 to $3.5 \mathrm{~cm}$ ) and more ridged in the wound-inoculation assays than in nonwound-inoculation assays (diameter $=0.2$ to $1.5 \mathrm{~cm}$ ) on Golden Delicious, Red Delicious, and Gala. The symptoms of both wound-inoculation assays (diameter $=0.5$ to $2.0 \mathrm{~cm}$ ) and nonwoundinoculation assays (diameter $=0.2$ to $0.8 \mathrm{~cm}$ ) on Fuji were slighter than those on the other three cultures.

Isolate QXHD_10 caused characteristic moldy core symptoms on apple when inoculated with either hyphae or conidial suspensions. The moldy core symptoms on carpels were observed 5 days after inoculation. Lesions on Fuji were smaller those on than Golden Delicious, Red Delicious, or Gala (Fig. 2).

Ten days after leaves were inoculated with mycelial plugs, slight chlorosis (diameter $=0.6$ to $1.5 \mathrm{~cm}$ ) appeared around sites of inoculation with mycelial plugs on Golden Delicious, Red Delicious, and Gala in the detached-leaf assay, whereas no lesions were observed after inoculation by conidial suspensions. On Fuji, however, no symptoms were observed when inoculated with either mycelial plugs or conidial suspensions (Fig. 3).

Phylogeny. The combined gene alignment of GAPDH, RPB2, and TEF1 that included 1,848 characters (including gaps) was used in the phylogenetic analysis of isolates BSBD_86 and QXHD_10. Sequences of 59 isolates listed in Table 2 were obtained from GenBank, including the outgroup $S$. herbarum (CBS 191.86), were used to construct a phylogeny of closely related Alternaria genera.

For Bayesian inference, this dataset included 1,848 characters (including gaps). The HKY $+\mathrm{I}+\mathrm{G}$ model was selected for GAPDH and the GTR+I+G model for RPB2 and TEF1. The Bayesian analysis lasted 405,000 generations and the consensus trees and posterior probabilities (PP) were calculated from the 812 trees left after discarding 406 trees (the first $25 \%$ of generations). The Bayesian analysis produced phylogenetic trees with the same topology as the RAxML tree; therefore, only the Bayesian tree is shown (Fig. 4), with RAxML bootstrap support values (MLBS) plotted on the tree. The phylogenetic trees (Fig. 4) delimited 24 clades. Isolates BSBD_86 and QXHD_10 in this study were clustered into sect. Ulocladioides.

The combined gene alignment of the GAPDH-Alta1-MAT(1-2-1)AGA dataset consisted of 24 isolates selected based on species of Ulocladium that were similar in morphology, as well as A. alternata (CBS 916.96) as the outgroup. This dataset included 3,367 characters (including gaps). The GTR $+\mathrm{I}+\mathrm{G}$ model was selected for the Bayesian
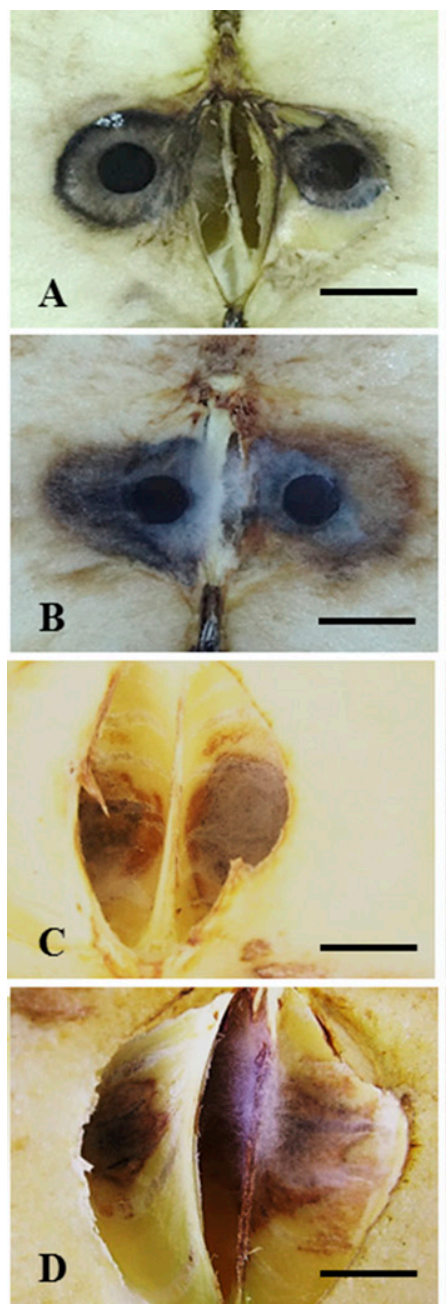
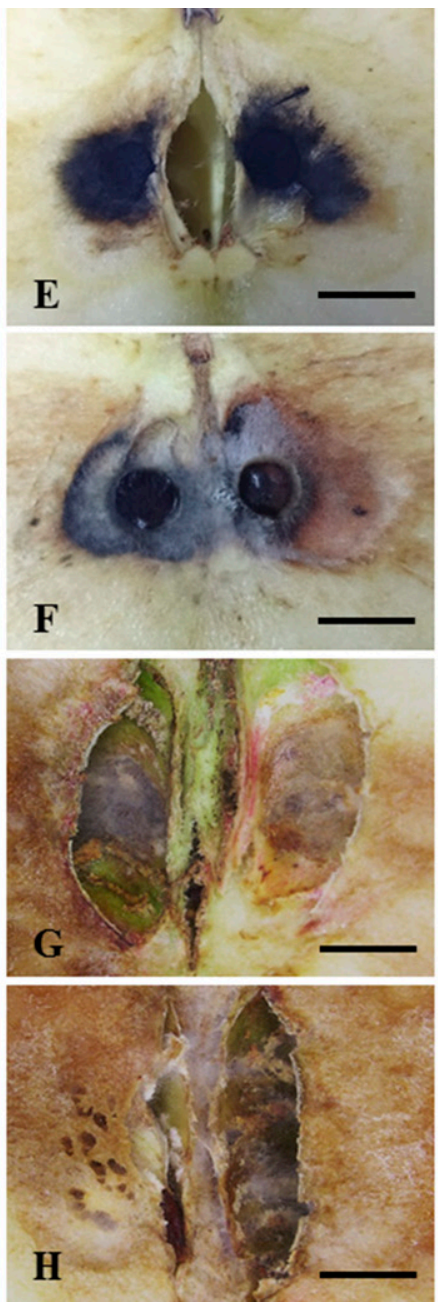
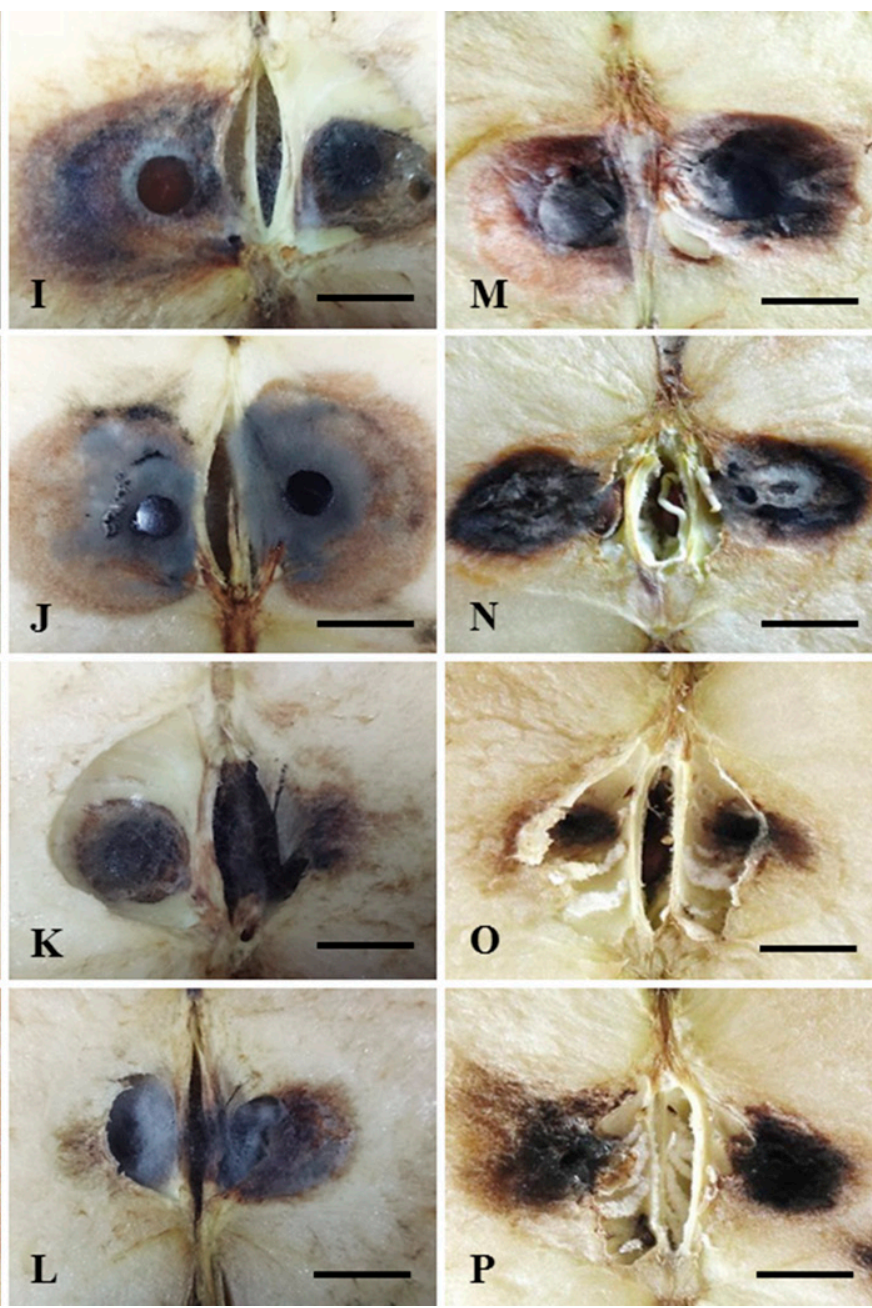

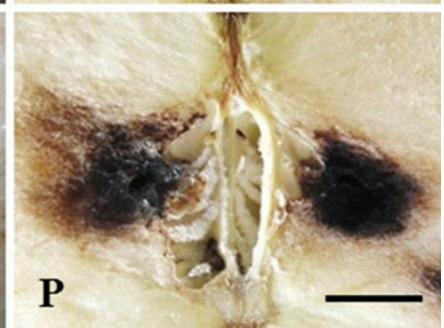

Fig. 2. Symptoms on fruit carpels of Golden Delicious, Red Delicious, and Gala inoculated with Alternaria malicola isolate QXHD_10. A to D, Golden Delicious; E to H, Red Delicious; I to L, Gala; and M to P, Fuji. A, C, E, G, I, K, M, and O were inoculated without wounding; B, D, F, H, J, L, N, and P were wound inoculated. A, B, E, F, I, J, M, and $\mathrm{N}$ were inoculated by hyphae; $\mathrm{C}, \mathrm{D}, \mathrm{G}, \mathrm{H}, \mathrm{K}, \mathrm{L}, \mathrm{O}$, and $\mathrm{P}$ were inoculated by conidium suspensions. All symptoms were photographed 5 days after inoculation. Scale bars $=1.0 \mathrm{~cm}$. 
analysis. This analysis lasted 480,000 generations and the consensus trees and PP were calculated from the 962 trees remaining after discarding 481 trees (the first $25 \%$ of generations) for burn-in. The Bayesian analyses produced phylogenetic trees with the same topology as the RAxML tree; therefore, only the Bayesian tree is presented (Fig. 5), with ML bootstrap values plotted on the tree. The Bayesian PP > 0.95 and MLBS > 50\% were plotted against the tree (Fig. 5). Isolates BSBD_86 and QXHD_10 in this study were categorized from other species with high bootstrap support (1.0/90\%).

Taxonomy. Alternaria malicola G. Y. Sun \& Jiling Dang, sp. nov.

Colonies on PCA: Hyphae thin- to slightly thin-walled, hyaline to pale grayish, smooth, vegetatively branched, septate, ramose, aerial, 2.5 to $4 \mu \mathrm{m}$ wide. Conidiophores produced laterally or terminally on the hyphae, erect or ascending, simple or branched, geniculate, pale brown, smooth, 1 to 4 septa, 10 to $60 \times 3$ to $4.5 \mu \mathrm{m}$, arising mostly at right angles from undifferentiated hyphae, conspicuous scars after conidia have fallen off (Figs. $6 \mathrm{C}$ to $\mathrm{F}$ and $7 \mathrm{~A}$ and $\mathrm{B}$ ). Conidia numerous, acrogenous or acropleurogenous, sympodial proliferations, solitary, noncatenulate. Neonatal conidia subhyaline or pale grayish, ellipsoidal or subacute, thick-walled, 1 to 3 septa, with few or no protuberance (Figs. 6C and $\mathrm{E}$ and 7C). Mature conidia brown to dark chocolate-brown, spheroidal or ellipsoid to long-ellipsoid, nonbeaked or with slightly cuspidal top, verrucose protuberances or densely tuberculate or irregular shaped protuberances, that were more common on mature conidia, with 1 to 5 transverse septa and 1 to 3 longitudinal septa or oblique septa, 16 to $35 \times 8$ to $16 \mu \mathrm{m}$, med. $25.5 \times 12 \mu \mathrm{m}, \mathrm{L} / \mathrm{W}=2$ to 2.2 , med. 2.1 (Figs. $6 \mathrm{C}$ to $\mathrm{F}$ and $7 \mathrm{E}$ and $\mathrm{F})$.
Colonies on PDA brown to dark brown, rapidly covering the Petri dish within 7 days. Concentric zonation of growth pronounced, and sporulation abundant. Mycelium subhyaline to dilute yellowish brown.

Holotype: CHINA. Shaanxi: Qianxian. From fruit of apple (Malus $\times$ domestica) 'Fuji', Oct 2015, J. L. Dang, (Holotypus HMAS 247403, ex-type culture CGMCC3.18704 = QXHD_10).

Specimen examined: China, Shaanxi Province, Baishui County. From fruit of apple (Malus $\times$ domestica) 'Fuji', Oct 2015, J. L. Dang, culture BSBD_86.

Notes: Distinguishing characteristics of this new species and other similar well-known species of Ulocladium are shown in Table 1. In conidium morphology, this new fungus is distinct from $U$. capsici (Xue and Zhang 2007), U. leve (Liu and Zhang 2008), U. consortiale (Simmons 1967), U. oblong-obovoideum (Zhang and Zhang 2002), U. sorghi (Zhang and Zhang 2006), U. castaneae (Zhang and Zhang 2002), U. populi (Shipunov et al. 2009), A. cantlous (Wang et al. 2010), A. subcucurbitae (Wang et al. 2008), and U. microsporum (Moubasher and Abdei-Hafez 1977) in having coarse or verrucose protuberances, whereas the other species possess conidial surfaces that are rarely or only slightly verruculose. The conidia of $U$. lignicola (Nagaraju et al. 2009) have 3 to 6 transverse septa with small tubercles and those of $U$. gpagarwalii (Nagaraju et al. 2009) have 0 to 3 transverse septa, whereas our new species has 1 to 5 transverse septa. Conidial ornamentation similar to that of our new species occurs in $U$. populi (Shipunov et al. 2009); however, the latter conidia have more septa (3 to 6 transverse septa and 1 to 4 longisepta) than our new species. The conidia of $U$. arborescens (Simmons 2004) may remain solitary or more commonly proliferate in branching chains, and
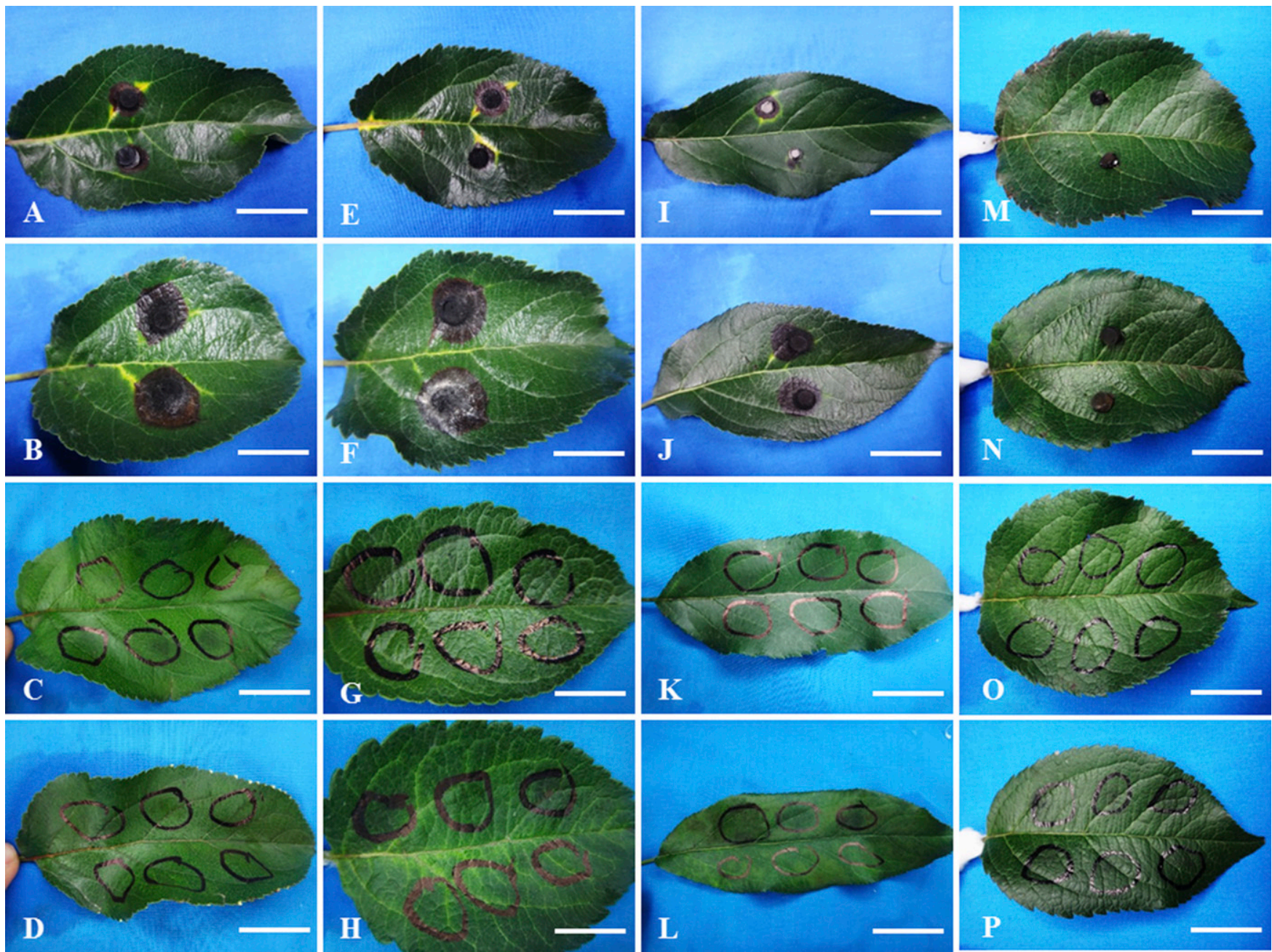

Fig. 3. Symptoms on leaves of Golden Delicious, Red Delicious, and Gala inoculated by Alternaria malicola isolate QXHD_10. A to D, Golden Delicious; E to H, Red Delicious; I to L, Gala; and M to P, Fuji. A, C, E, G, I, K, M, and O were inoculated without wounding; B, D, F, H, J, L, N, and P were wound inoculated. A, B, E, F, I, J, M, and N were inoculated by hyphae; C, D, G, H, K, L, O, and P were inoculated by conidium suspensions. All symptoms were photographed 10 days after inoculation. $S$ cale bars $=1.0 \mathrm{~cm}$. 


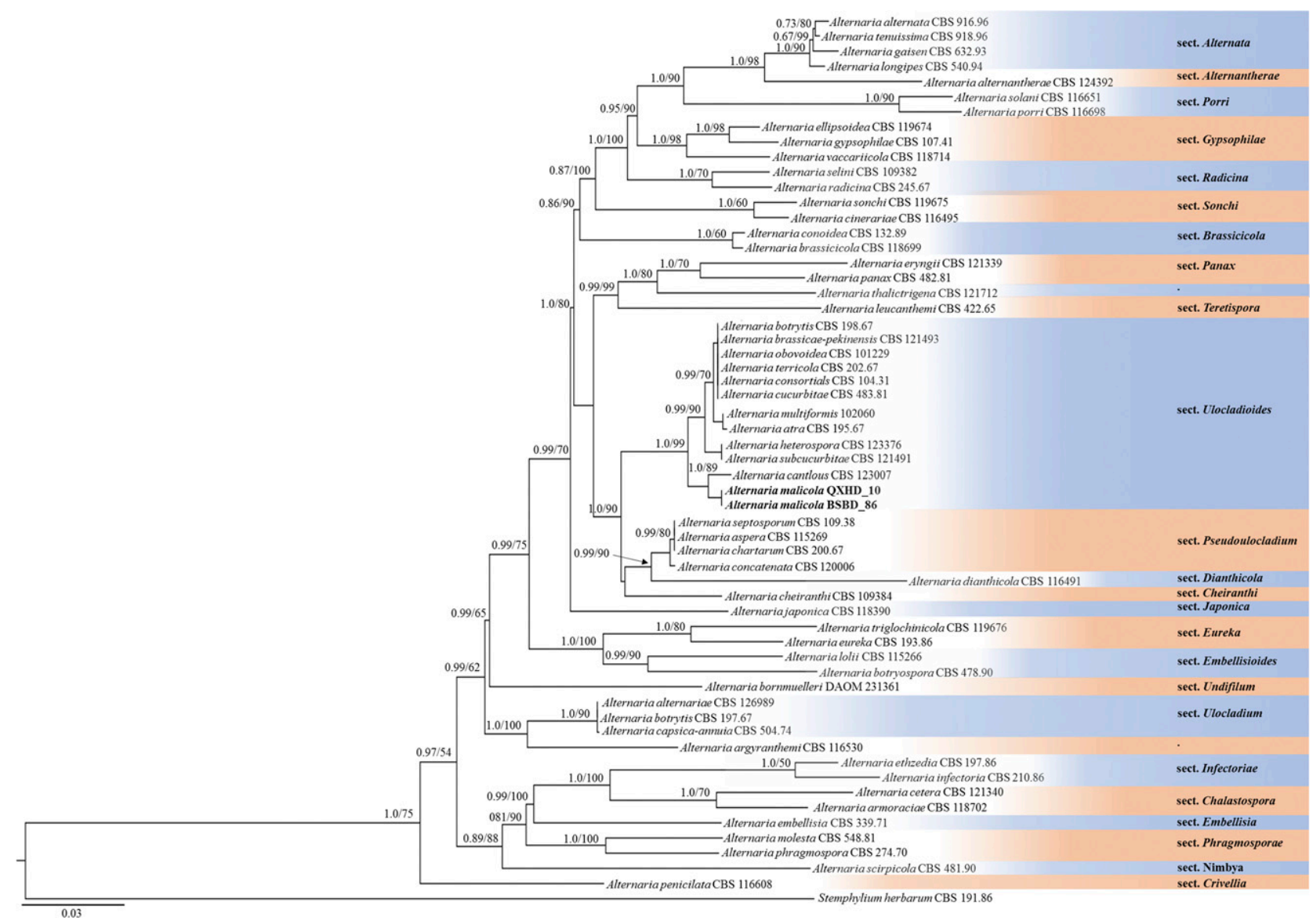

Fig. 4. Bayesian $50 \%$ majority rule consensus tree based on the glyceraldehyde-3-phosphate dehydrogenase, RNA polymerase second largest subunit, and translation elongation factor 1 - $\alpha$ sequences of 59 strains representing the Altermaria complex. The Bayesian posterior probabilities (PP) and RAxML bootstrap support values (ML) are given at the nodes (PP/ML). The tree was rooted to Stemphylium herbarum (CBS 191.86). Monotypic lineages are indicated by black dots. New sequences (BSBD_86 and QXHD_10) generated in this study are printed in bold.

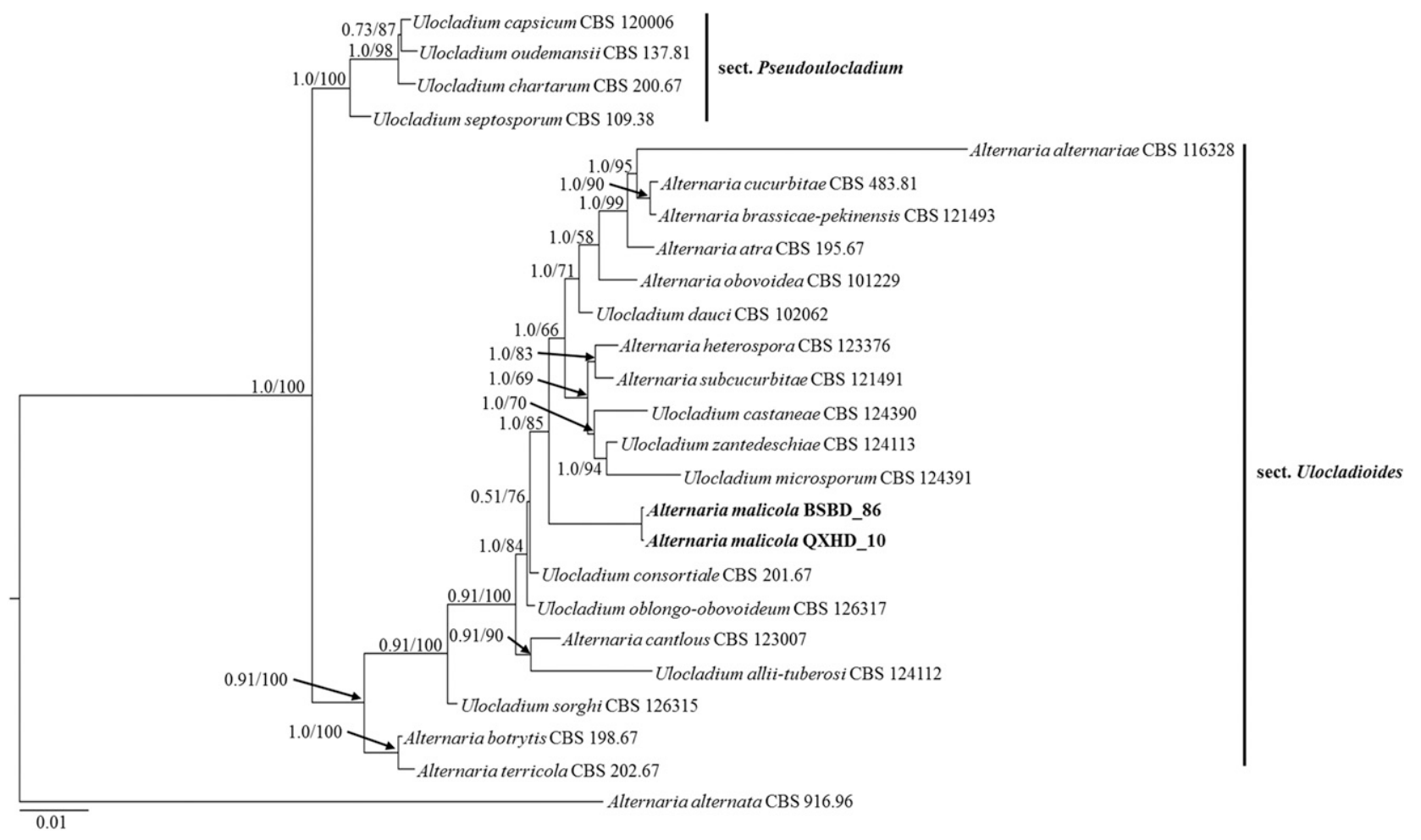

Fig. 5. Bayesian 50\% majority rule consensus tree based on the glyceraldehyde-3-phosphate dehydrogenase, allergen Alta1, mating type protein 1-2-1, and the AGA1 gene sequences of strains representing Ulocladium. The Bayesian posterior probabilities (PP) and RAxML bootstrap support values (ML) are given at the nodes (PP/ML). The tree was rooted to Alternaria alternata (CBS 916.96). New sequences (BSBD_86 and QXHD_10) generated in this study are printed in bold. 
secondary spore production is by means of well-defined secondary conidiophores; both are distinct from our new species, which proliferates without branching chains. Additional distinctions of the new species from other species of Ulocladium are shown in Table 1.

\section{Discussion}

The genus Alternaria was originally described by Nees von Esenbeck (1816), based on A. tenuis as the type species. In the past, classification and identification of Alternaria spp. were dominated by description of morphological characteristics of conidia and conidiation patterns (Simmons 1967). Molecular phylogeny was used to supplement morphology-based identification (Kusaba and Tsuge 1995; Peever et al. 2004). Sequence analysis of the GAPDH, RPB2, and TEF1 gene regions were used most widely to analyze phylogenetic diversity among the Alternaria spp. groups. Currently, the genus Alternaria is considered to be a complex comprising 24 internal clades and

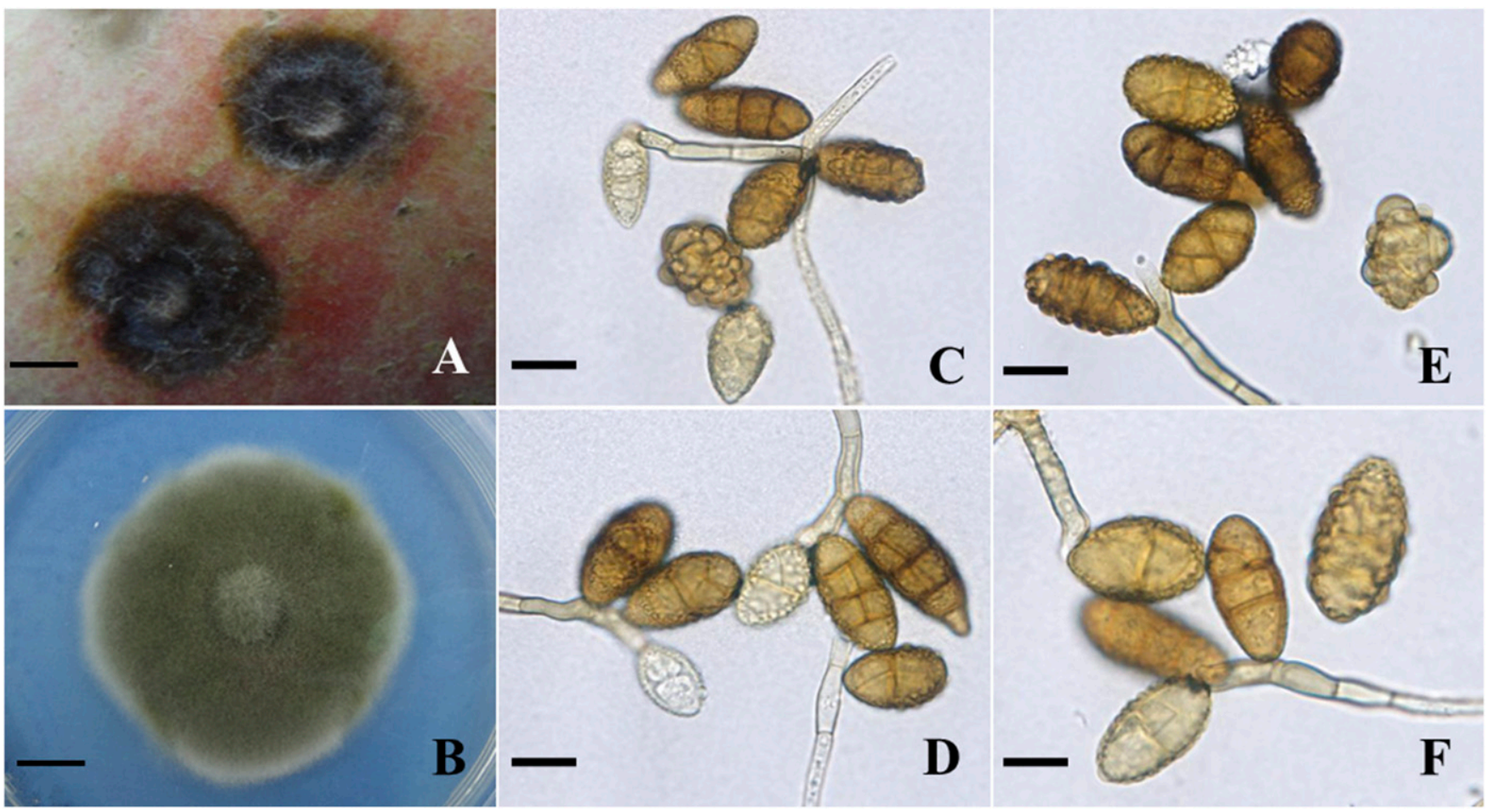

Fig. 6. Microscopic morphology of Alternaria malicola isolate QXHD_10. A, Colonies on apple in close-up view; B, colony on potato dextrose agar after 1 week; and $\mathbf{C}$ to F, sympodial conidiophores and conidia on potato carrot agar. Scale bars: $A=2 \mathrm{~mm}, B=5 \mathrm{~mm}$, and $C$ to $F=10 \mu \mathrm{m}$.
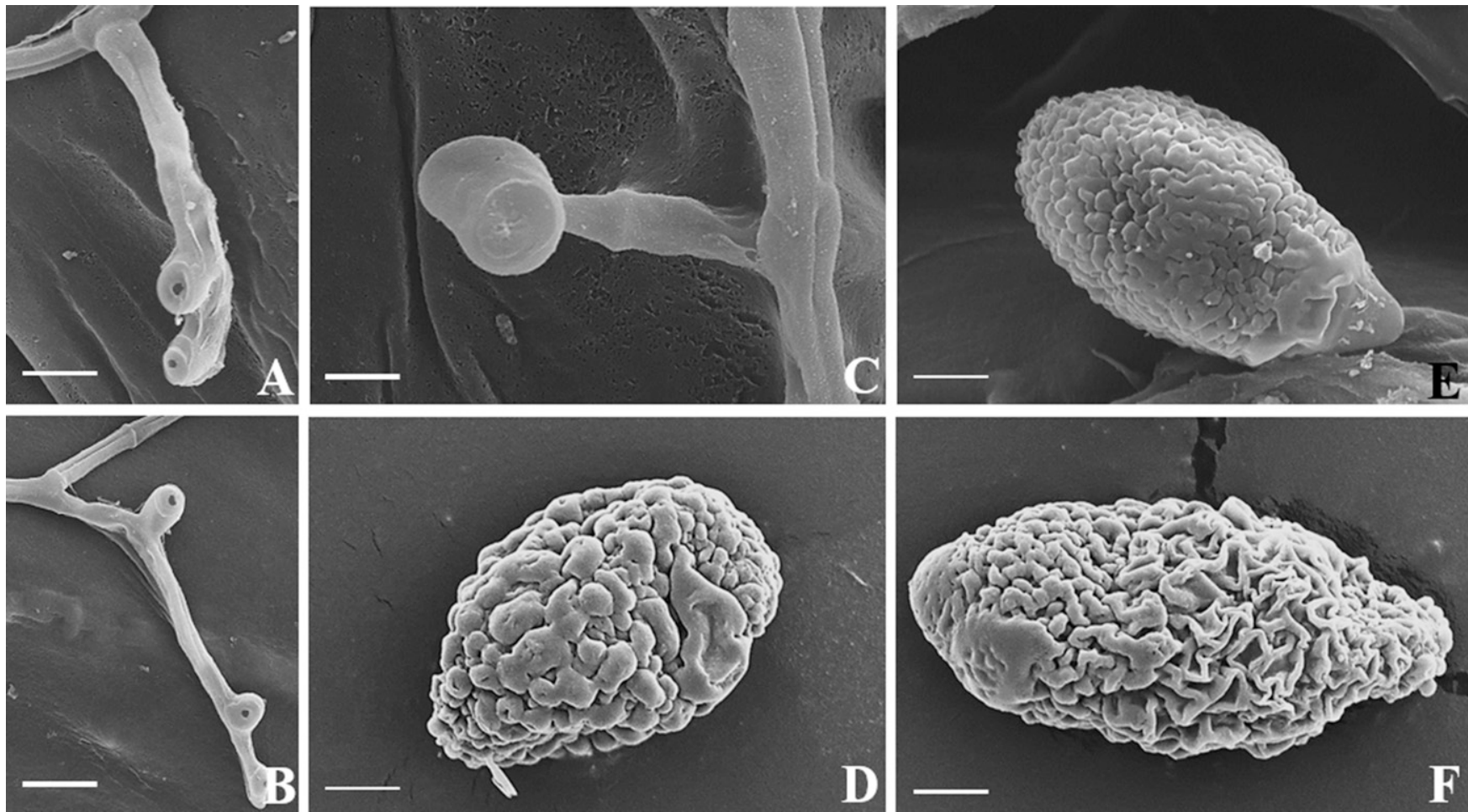

Fig. 7. Scanning electron micrographs of Alternaria malicola isolate QXHD_10 showing conidiophores and scars, conidial ornamentation. $\mathbf{A}$ and $\mathbf{B}$, Conidiophores and scars; C, neonatal conidia; and $\mathbf{D}$ to $F$, mature conidia and ornamentation. Scale bars: $A, B$, and $C=5 \mu \mathrm{m}$ and $D, F$, and $E=10 \mu \mathrm{m}$. 
six monotypic lineages. The 24 internal clades were treated as sections, which is a continuation of a recent proposal for the taxonomic treatment of lineages in Alternaria (Woudenberg et al. 2013). Alternaria sect. Alternaria included 11 phylogenetic species and one species complex based on genome and transcriptome comparisons and molecular phylogenies. In total, 35 morphospecies, which cannot be distinguished based on multigene phylogeny, are synonymized under A. alternata (Woudenberg et al. 2015).

The genus Ulocladium was first created by Preuss (1851), with $U$. botrytis designated as the type species. In the past, Ulocladium was equal with Alternaria and Stemphylium in taxonomic position, and shared several characteristics of the juvenile and mature shapes of conidia, as well as modes of proliferation of conidiophores and conidia (Simmons 1967). In combination with a review of literature and morphology, the species within the Alternaria clade are all recognized here as Alternaria sensu stricto, placing the genus Ulocladium in synonymy with Alternaria. Suggestions to synonymize Ulocladium with Alternaria have been made several times (Pryor and Gilbertson 2000), and the genus Ulocladium has been assigned to the Alternaria complex (Woudenberg et al. 2013). Species of Ulocladium were clustered into three sister clades of this complex, now called sect. Ulocladium, sect. Ulocladioides, and sect. Pseudoulocladium (Woudenberg et al. 2013). Our isolates QXHD_10 and BSBD_86 were clustered into sect. Ulocladioides.

The taxonomic classification of species of Ulocladium is based primarily on morphological characteristics, including conidial shape, size range, septation, ornamentation, catenulation, and presence or absence of a beak (apical extension) (Simmons 1967). However, morphological characteristics of species of Ulocladium can vary when grown under different cultural conditions, and have caused difficulty in establishing new taxa, even when comparing the sporulation elements under standardized conditions (Simmons 1998). Therefore, it became important to use molecular genetic analysis for further examination of the relationships among Ulocladium spp. The nuclear internal transcribe spacer, small subunit rRNA gene (mt SSU), GAPDH, and Alta1 gene sequences have been used extensively in the resolution of phylogenetic relationships among Ulocladium spp. (Hong et al. 2005; Lawrence et al. 2012, 2013; Pryor and Gilbertson 2000). Later, using the MAT genes to identify and characterize the species of Ulocladium was suggested (Geng et al. 2014). MAT genes appear to evolve faster than some other regions in the genome, and high interspecific variation and low dissimilarity within species make the MAT genes more appropriate than other regions of the genome for species delimitation (Turgeon 1998; Voigt et al. 2005).

Species of Ulocladium colonize a variety of habitats, including soil, air, and plants (Preuss 1851; Saccardo 1886; Simmons 1967, 1998). A few species of Ulocladium isolated from plant leaves are associated with leaf lesions. U. cucurbitae incites a widespread leaf spot disease of cucurbits (Simmons 1998). U. chartarum is the causal agent of a leaf necrosis on Quercus pubescens (Vannini and Vettraino 2000). U. capsicuma was discovered on leaves of Capsicum annuиm L., Wang described species U. subcucurbitae and U. brassicae from diseased leaves of Chenopodium glaucum and Brassica pekinensis (Wang et al. 2008) and U. cantlous from Cucumis sp. (Wang et al. 2010). U. obovoideum was discovered on lemon (Simmons 1990) and Citrus sinensis (Zhang and Zhang 2002). However, no species has been described from apple.

Combining results of phylogeny, morphology, and pathogenicity assessments on apple in our study indicated that isolate QXHD_10 is a newly described pathogen of black dot of apple. This species can cause symptoms on leaves and carpels of apple in vitro as well. However, just two isolates were obtained and the symptoms have not been found in the field. We speculate that the species is a potential or secondary pathogen associated with all three diseases: black dot, Alternaria leaf blotch, and moldy core. The results of the present study further broaden understanding of the diversity of fungi in the Alternaria complex, and are likely to be useful to plant pathologists and fruit breeders in improving management of these diseases. However, further studies are required to characterize the association of A. malicola with leaf lesions and moldy core of apple and its pathogenic potential.

\section{Acknowledgments}

We thank Prof. Xiuguo Zhang, College of Plant Protection, Shandong Agricultural University, Tai'an, China, for providing Alternaria isolates.

\section{Literature Cited}

Andersen, B., Hansen, M. E., and Smedsgaard, J. 2005. Automated and unbiased image analyses as tools in phenotypic classification of small-spored Alternaria spp. Phytopathology 95:1021-1029.

Berbee, M. L., Pirseyedi, M., and Hubbard, S. 1999. Cochliobolus phylogenetics and the origin of known, highly virulent pathogens, inferred from ITS and glyceraldehyde-3-phosphate dehydrogenase gene sequences. Mycology 91: 964-977.

Bottalico, A., and Logrieco, A. 1992. Alternaria plant diseases in Mediterranean countries and associated mycotoxins. Pages 209-232 in: Alternaria: Biology, Plant Diseases and Metabolites. J. Chelkowski and A. Visconti, eds. Elsevier, Amsterdam.

Carbone, I., and Kohn, L. M. 1999. A method for designing primer sets for speciation studies in filamentous ascomycetes. Mycology 91:553-556.

Combrink J. C., Kotzé, J. M., Wehner, F. C., and Grobbelaar, C. J. 1985. Fungi associated with core rot of staking apples in South Africa. Phytophylactica 17:81-83

Crous, P. W., Gams, W., Stalpers, J. A., Robert, V., and Stegehuis, G. 2004 MycoBank: An online initiative to launch mycology into the 21st century. Stud. Mycol. 50:19-22.

Crous, P. W., Verkley, G. J. M., Groenewald, J. Z., and Samson, R. A. 2009. Fungal Biodiversity. CBS Laboratory Manual Series 1. CBS-KNAW Fungal Biodiversity Centre, Utrecht, The Netherlands.

Edgar, R. C. 2004. MUSCLE: Multiple sequence alignment with high accuracy and high throughput. Nucleic Acids Res. 32:1792-1797.

Filajdic, N., and Sutton, T. B. 1991. Identification and distribution of Alternaria mali on apples in North Carolina and susceptibility of different varieties of apples to Alternaria blotch. Plant Dis. 75:1045-1048.

Gao, L. L., Zhang, Q., Sun, X. Y., Jiang, L., Zhang, R., Sun, G. Y., Zha, Y. L., and Biggs, A. R. 2013. Etiology of moldy core, core browning, and core rot of Fuji apple in China. Plant Dis. 97:510-516.

Geng, Y., Li, Z., Xia, L. Y., Wang, Q., Hu, X. M., and Zhang, X. G. 2014 Characterization and phylogenetic analysis of the mating-type loci in the asexual ascomycete genus Ulocladium. Mycologia 106:649-665.

Guo, Y. Z., Sun, G. Y., Gao, B. W., Li, C. Y., Zhang, P. L., and Lei, X. L. 2005 Studies on the identification of pathogen and the biological characteristics of black-dot disease of bagged apple. Acta Agric. Boreali-Occident. Sin. 14: $18-21$

Hall T. A. 1999. BioEdit: A user-friendly biological sequence alignment editor and analysis program for Windows 95/98/NT. Nucleic Acids Symp. Ser. 41:95-98.

Hao, X. A., Wu, Y. F., Zhou, X. M., Yang, Y., Wang, X. M., and Liu, S. B. 2004 Preliminary studies on the identification and occurrence of black-dot disease on bagged apple fruit in Shaanxi. Acta Agric. Boreali-Occident. Sin. 13:54-57.

Harteveld, D. O. C., Akinsanmi, O. A., and Drenth, A. 2014. Pathogenic variation of Alternaria species associated with leaf blotch and fruit spot of apple in Australia. Eur. J. Plant Pathol. 139:789-799.

Hong, S. G., Cramer, R. A., Lawrence, C. B., and Pryor, B. M. 2005. Alta1 allergen homologs from Alternaria and related taxa: Analysis of phylogenetic content and secondary structure. Fungal Genet. Biol. 42:119-129.

Hu, T. L., Wang, S. T., Song, P., Zhang, F. Q., Zhen, W. C., and Cao, K. Q. 2006. Primary study on the crucial weather conditions of mass infection of Alternaria mali on apple. J. Hebei Agric. Univ. 29:63-66.

Kusaba, M., and Tsuge, T. 1995. Phylogeny of Alternaria fungi known to produce host-specific toxins on the basis of variation in internal transcribed spacers of ribosomal DNA. Curr. Genet. 28:491-498.

Lawrence, D. P., Gannibal, P. B., Peever, T. L., and Pryor, B. M. 2013. The sections of Alternaria: Formalizing species-groups concepts. Mycology 105 530-546.

Lawrence, D. P., Park, M. S., and Pryor, B. M. 2012. Nimbya and Embellisia revisited, with nov. comb for Alternaria celosiae and A. perpunctulata. Mycol. Prog. 11:799-815.

Li, Y., Zhang, L. Y., Zhang, Z., Cong, P. H., and Cheng, Z. M. 2011. A simple sequence repeat marker linked to the susceptibility of apple to Alternaria blotch caused by Alternaria alternata apple pathotype. J. Am. Soc. Hortic. Sci. 136:109-115

Liu, H. M., and Zhang, T. Y. 2008. A new species and two new records of Ulocladium from China. Mycosystema 27:1-4.

Liu, Y. J., Whelen, S., and Hall, B. D. 1999. Phylogenetic relationships among ascomycetes: Evidence from an RNA polymerase II subunit. Mol. Biol. Evol. 16:1799-1808

Moubasher, A. H., and Abdei-Hafez, S. I. 1977. Ulocladium microsporum sp. nov. Trans. Br. Mycol. Soc. 69:164-166. 
Nagaraju, D., Kunwar, I. K., Manoharachary, C., and Agarwal, D. K. 2009. Ulocladium gpagarwalii and $U$. lignicola two new sp. nov. from Andhra Pradesh. Indian Phytopathol. 62:237-239.

Nees von Esenbeck C. G. D. 1816. Das system der pilze und schwämme. In der Stahelschen buchhandlung, 1816-1817, Wurzburg, Germany.

Nylander, J. A. A. 2004. MrModeltest V2. Program distributed by the author. Evolutionary Biology Centre, Uppsala University.

Page, R. D. M. 1996. TreeView: An application to display phylogenetic trees on personal computers. Comput. Appl. Biosci. 12:357-358.

Peever, T. L., Su, G., and Carpenter-Boggs, L. 2004. Molecular systematics of citrus-associated Alternaria species. Mycology 96:119-134.

Preuss, C. G. T. 1851. Übersicht untersuchter pilze, besonders aus der Umgegend von Hoyerswerda. Linnaea 24:99-153.

Pryor, B. M., and Gilbertson, R. L. 2000. Molecular phylogenetic relationships amongst Alternaria species and related fungi based upon analysis of nuclear ITS and mt SSU rDNA sequences. Mycol. Res. 104:1312-1321.

Ren, P., Ahearn, D. G., and Crow, S. A. 1998. Mycotoxins of Alternaria alternata produced on ceiling tiles. J. Ind. Microbiol. Biotechnol. 20:53-54.

Roberts, J. W. 1924. Morphological characters of Alternaria mali Roberts. J. Agric. Res. 27:699-712.

Ronquist, F., and Huelsenbeck, J. P. 2003. MrBayes 3: Bayesian phylogenetic inference under mixed models. Bioinformatics 19:1572-1574.

Saccardo, P. A. 1886. Sylloge Fungorum Omnium hucusque cognitorum, Vol. 4. Nabu Press, Padua, Italy.

Sawamura, K. 1962. Studies on spotted disease of apple 1. Causal agent of Alternaria blotch. Bull. Tohoku Natl. Agric. Exp. Stn. 23:163-175.

Serdani, M., Crous, P. W., Holz, G., and Petrini, O. 1998. Endophytic fungi associated with core rot of apples in South Africa, with specific reference to Alternaria species. Sydowia 50:257-271.

Shipunov, A., Raghavendra, A. K., Ganley, R. J., and Newcombe, G. 2009. Ulocladium populi E.G. Simmons, G. Newcombe \& A. Shipunov, sp. nov. Fungal Planet 34:1-2.

Simmons, E. G. 1967. Typification of Alternaria, Stemphylium, and Ulocladium. Mycology 59:67-92.

Simmons, E. G. 1990. Alternaria themes and variations. Mycotaxon 37:79-119.

Simmons, E. G. 1998. Multiplex conidium morphology in species of the Ulocladium atrum group. Can. J. Bot. 76:1533-1539.

Simmons, E. G. 2004. Novel dematiaceous hyphomycetes. Stud. Mycol. 50:109-118.

Simmons, E. G., and Roberts, R. G. 1993. Alternaria themes and variations. Mycotaxon 48:109-140.

Spotts, R. A. 1990. Moldy core and core rot. Pages 29-30 in: Compendium of Apple and Pear Diseases. A. L. Jones and H. S. Aldwinckle, eds. American Phytopathological Society, St. Paul, MN.
Stamatakis, A. 2006. RAxML-VI-HPC: Maximum likelihood-based phylogenetic analyses with thousands of taxa and mixed models, v. 7.03. Bioinformatics 22: 2688-2690.

Strandberg, J. O. 1992. Alternaria species that attack vegetable crops: Biology and options for disease management. Pages 175-208 in: Alternaria: Biology, Plant Diseases and Metabolites. J. Chelkowski and A. Visconti, eds. Elsevier, Amsterdam.

Sung, G. H., Sung, J. M., Hywel-Jones, N. L., and Spatafora, J. W. 2007. A multi-gene phylogeny of Clavicipitaceae (Ascomycota, Fungi): Identification of localized incongruence using a combinational bootstrap approach. Mol. Phylogenet. Evol. 44:1204-1223.

Turgeon, B. G. 1998. Application of mating type gene technology to problems in fungal biology. Annu. Rev. Phytopathol. 36:115-137.

Vannini, A., and Vettraino, A. M. 2000. Ulocladium chartarum as the causal agent of a leaf necrosis on Quercus pubescens. For. Pathol. 30:297-303.

Verkley, G. J. M. 1999. A monograph of the genus Pezicula and its anamorphs. Stud. Mycol. 44:1-180.

Voigt, K., Cozijnsen, A. J., Kroymann, J., Pöggeler, S., and Howlett, B. J. 2005 Phylogenetic relationships between members of the crucifer pathogenic Leptosphaeria maculans species complex as shown by mating type (MAT1-2), actin and beta-tubulin sequences. Mol. Phylogenet. Evol. 37:541-557.

Wang, C. C., Jin, J., Li, B. H., Wang, C. X., Dong, X. L., and Zhang, Z. F. 2014 Pathogens isolated from different symptoms of black dot disease and infection conditions. Acta Agric. Boreali-Sin. 29:136-144.

Wang, Y., Pei, Y. F., O'Neill, N. R., and Zhang, X. G. 2008. Two new species of Ulocladium from Southwest China. Mycology 100:455-459.

Wang, Y., Pei, Y. F., O'Neill, N. R., and Zhang, X. G. 2010. Ulocladium cantlous sp. nov. isolated from northwestern China: Its morphology and molecular phylogenetic position. Mycology 102:374-383.

Woudenberg, J. H. C., Groenewald, J. Z., Binder, M., and Crous, P. W. 2013. Alternaria redefined. Stud. Mycol. 75:171-212.

Woudenberg, J. H. C., Seidl, M. F., Groenewald, J. Z., De Vries, M., Stielow, J. B., Thomma, B. P. H. J., and Crous, P. W. 2015. Alternaria section Alternaria: Species, formae speciales or pathotypes? Stud. Mycol. 82:1-21.

Xu, B. L., Wei, Z. Z., and Wang, X. L. 2000. Symptoms and identification of black dot disease on apple fruit. Plant Prot. 26:6-8.

Xue, F., and Zhang, X. G. 2007. Ulocladium capsicuma, a new species identified by morphological and molecular phylogenetic data. Sydowia 59: $161-178$

Zhang, X. G., and Zhang, T. Y. 2002. Studies on the genus Ulocladium Preuss from China I. Mycosystema 21:25-26.

Zhang, X. G., and Zhang, T. Y. 2006. Studies on the genus Ulocladium Preuss from China II. Mycosystema 25:516-520. 